\title{
A polymerase chain reaction (PCR) to detect epizootic haematopoietic necrosis virus and Bohle iridovirus
}

\author{
Allan R. Gould ${ }^{1}$, Alex D. Hyatt ${ }^{1, *}$, Sandra H. Hengstberger ${ }^{1}$, R. J. Whittington ${ }^{2}$, \\ Barbara E. H. Coupar ${ }^{1}$ \\ 'Australian Animal Health Laboratory, C.S.I.R.O., PO Bag 24, Geelong, Victoria 3220, Australia \\ ${ }^{2}$ Elizabeth Macarthur Agricultural Institute, NSW Agriculture, PMB 8, Camden, New South Wales 2570, Australia
}

\begin{abstract}
The polymerase chain reaction (PCR) was used to amplify a segment of DNA of the dsDNA genome of epizootic haematopoietic necrosis virus (EHNV). PCR primers were synthesised which spanned an open reading frame. After 30 cycles of amplification of EHNV and Bohle iridovirus (BIV) genomic DNA, PCR products from the primers (P505 and P506) were visible on agarose gels stained with ethidium bromide. No PCR products were obtained from diamond python erythrocytic iridovirus (DPEV) or fish lymphocystis disease virus (FLDV) DNA. EHNV isolates from redfin perch Perca fluviatilis L., rainbow trout Oncorhynchus mykiss Walbaum and BIV isolates from the ornate burrowing frog Limnodynastes ornatus Gray and barramundi Lates calcarifer generated PCR products of $235 \mathrm{bp}$. The tests were used to amplify DNA extracted from EHNV-infected cell. cultures and infected tissues from redfin perch, rainbow trout and barramundi. Specificity of the test was assessed by attempting to amplify DNA from uninfected cell cultures and tissues from uninfected rainbow trout, redfin perch and viruses such as DPEV and FLDV which have not been classified within the iridovirus genus Ranavirus but have been isolated from fish and reptiles within Australia. Hybridisation of ${ }^{32} \mathrm{P}-$ labelled EHNV PCR amplified DNA to Southern blots of Ncol restriction endonuclease digested EHNV and BIV DNA enabled the easy differentiation of EHNV and BIV isolates. The PCR assay described in this paper provides a rapid method to detect/differentiate EHNV and BIV and is a valuable addition to the current EHNV diagnostic tests.
\end{abstract}

KEY WORDS: Iridovirus - PCR - EHN virus - Bohle virus

\section{INTRODUCTION}

Epizootic haematopoietic necrosis virus (EHNV) was isolated in Victoria (Australia) from redfin perch Perca fluviatilis L. in 1986 (Langdon et al. 1986). Since then, epizootics have been reported within wild redfin populations in 3 Australian states [Victoria, New South Wales (NSW) and South Australial and in cultured rainbow trout Oncorhynchus mykiss (Walbaum) (Hengstberger et al. 1993, Whittington et al. 1994). The virus is also known to cause disease experimentally in a range of Australian native fish (Langdon 1989).

\footnotetext{
- Addressee for correspondencè
}

Within Australia other iridoviruses have been found, including fish lymphocystis virus (Pearce et al. 1990), an erythrocytic iridovirus (DPEV) from the diamond python Morelia spilota (A. D. Hyatt \& H. Macraken unpubl.) and Bohle iridovirus (BIV) which was isolated from the ornate burrowing frog Limnodynastes ornatus (Gray) in Queensland (Speare \& Smith 1992). The family Iridoviridae encompasses 4 genera namely Iridovirus (represented by type 1 Tipula iridescent virus), Chloriridovirus (e.g. type 2 mosquito iridescent virus), Ranavirus (e.g. frog virus 3, FV3), Lymphocystisvirus (e.g. fish lymphocystis disease virus, FLDV) and a fifth proposed 'goldfish group' (Francki et al. 1991). Recent studies have compared EHNV with iridoviruses from the sheatfish Silurus glanis, the catfish Ictalurus melas 
and FV3 (Hedrick et al. 1992, Hengstberger et al. 1993). These studies showed that EHNV, BIV and FV3 belonged to the genus Ranavirus as do the sheatfish and catfish viruses (Essani \& Granoff 1989, Hedrick et al. 1992, Hengstberger et al. 1993).

EHNV has been isolated from both redfin perch and rainbow trout (Langdon et al. 1986, 1988). Antibodies have been raised against each of these isolates in addition to BIV (Hyatt et al. 1991, Steiner et al. 1991, Hengstberger et al. 1993, Whittington \& Steiner 1993) and used in diagnostic tests such as antigen capture ELISA and immunoelectron microscopy. When polyclonal antibodies against EHNV are applied to Western blots they can demonstrate differences in the molecular weights of some of the structural proteins (e.g the 38 and $45 \mathrm{kD}$ proteins) of trout and redfin isolates; whether these differences are attributable to strain or isolate differences is yet to be determined (Hengstberger et al. 1993). Although these antibodies also interact with BIV (Hengstberger et al. 1993) they do not react with FLDV or the recently isolated DPEV (Hyatt \& Macraken unpubl. data), nor can they detect concentrations of virus less than $10^{3.5} \mathrm{TCID}_{50} \mathrm{ml}^{-1}$ (Hyatt et al. 1991, Steiner et al. 1991, Whittington \& Steiner 1993).

A test which can detect low levels of virus and/or its nucleic acid is the polymerase chain reaction (PCR). This method generates detectable amounts of DNA from only a few copies of the target nucleic acid sequence by repeated cycles of DNA synthesis using a thermostable DNA polymerase and 2 sequence-specific primers that span a segment of the target genome. This paper describes the development of a PCR test for the rapid detection of DNA from EHNV and BIV.

\section{MATERIALS AND METHODS}

Virus isolates and cells. Isolates of EHNV (Table 1) and tissues from experimentally infected redfin perch and rainbow trout (Table 2) were used in this study. The isolates of EHNV were selected from a reference collection to represent a range of geographical areas across Victoria and NSW and the 2 host species from which the virus has been isolated. Other viruses included 2 isolates of BIV (Hengstberger et al. 1993), BIV(1) representing the original isolate (Speare \& Smith 1992) and BIV(2) from laboratory-BIV-infected barramundi Lates calcarifer (Moody \& Owens 1994); FLDV (Pearce et al. 1990) and DPEV. FV3, goldfish virus, sheatfish virus and catfish virus (see 'Introduction') were not used in this study as they are exotic to Australia and were not available at the time this study was undertaken because of importation restrictions.

All EHNV and BIV isolates, (samples 1 to 12) were passaged in bluegill fry (BF-2) cells (ATCC CCL 91) as described by Hengstberger et al. (1993). Samples 13 and 14 did not grow in cell culture and the samples therefore consisted of erythrocytes from a diamond python and nodular lesions from a barramundi respectively. In these latter samples, the presence of virus within these samples were confirmed by negative contrast electron microscopy and the examination of the relevant ultrathin sections by transmission electron microscopy (data not shown).

Samples of EHNV-infected redfin perch and rainbow trout tissues were obtained from experimentally infected fish. Rainbow trout were infected by intraperitoneal injection with strain 86/8774 (Table 2) and died 3 to $4 \mathrm{~d}$ later. Redfin perch were infected by bath inoculation with the same strain of EHNV and died 8 to $10 \mathrm{~d}$ later. Tissue samples from kidney, liver and spleen were collected and pooled for analyses. EHNV was detected by virus isolation from the tissues of 2 of the 3 rainbow trout and all 3 redfin as well as by ELISA in the tissues of all 6 fish. Uninfected redfin perch and rainbow trout tissues were obtained from fish collected from areas where epizootics of EHNV infection have never been reported. These samples were prepared for analyses as described by Whittington et al. (1994) and analysed by EHNV antigen-capture ELISA in addition to being passaged through BF-2 cells; all such samples were negative by virus isolation and ELISA antigen-capture ELISA.

Preparation of samples for PCR. Samples comprised tissue culture supernatants (samples 1 to 12) and clinical tissues (samples 13 to 18) (Tables 1 \& 2). As EHNV and BIV are associated with the insoluble cytoskeletal matrix of the host cells (Eaton et al. 1991) all samples were prepared by the methods described by Eaton et al. (1991), Hyatt et al. (1991), Hengstberger et al. (1993) or by Whittington \& Steiner (1993). All such samples were diluted to $15 \%(\mathrm{w} / \mathrm{v})$ in RSB $[10 \mathrm{mM}$ Tris $\mathrm{HCL}\left(\mathrm{pH} 7.4\right.$ ), $10 \mathrm{mM} \mathrm{NaCl}, 1.5 \mathrm{mM} \mathrm{MgCl}_{2}$ ]. Prior to each homogenisation the equipment was autoclaved, washed in $0.1 \mathrm{M} \mathrm{HCl}$ followed with $0.1 \mathrm{M} \mathrm{NaOH}$ and phosphate buffered saline (PBS). This procedure effectively inactivates any residual nucleic acid which may cause a false signal. Aliquots of the wash PBS were analysed to assess the preparative procedure for the presence of contaminating nucleic acids. Tissue cultwre supermatants and tissue homogenates, including erythrocytes, were diluted in $\mathrm{H}_{2} \mathrm{O}(1: 50)$, boiled for $5 \mathrm{~min}$, vortexed and then stored on wet ice.

Culture supernatants from EHNV-infected cell cultures were also used to assess the sensitivity of the test In these analyses the supernatants, which had a virus titre of $10^{7}$ plaque forming units $\mathrm{ml}^{-1}$, were serially diluted and the sample prepared for PCR as described above.

PCR primers and amplification of viral genomes. The genome of EHNV is approximately $125 \pm 10 \mathrm{~kb}$ 
Table 1 lsolates of Australian iridoviruses (epizootic haematopoietic necrosis virus, EHNV; Bohle iridovirus, BIV; fish lymphocystis disease virus, FLDV; diamond python erythrocytic irdovirus, DPEV) used in this study. TCS: tissue culture supernatant; NSW: New South Wales

\begin{tabular}{|c|c|c|c|c|c|}
\hline Virus & Isolate & Sample no. & Host species & Sample & Location \\
\hline \multirow[t]{10}{*}{ EHNV } & 9009041231 & 1 & Redfin perch & TCS & Lake Winnekie, Victoria \\
\hline & 9009031621 & 2 & Rainbow trout & TCS & Mt Dandenong, Victoria \\
\hline & 9009031622 & 3 & Redfin perch & TCS & Greenhill Lake, Ararat, Victoria \\
\hline & A91:00699103210069 & 4 & Redfin perch & $\mathrm{TCS}$ & Lake Mokoan, Victoria \\
\hline & ME: $91 / 78$ & 5 & Redfin perch & $\mathrm{TCS}$ & Lake Burley, Griffin \\
\hline & ME: $90 / 24$ & 6 & Redfin perch & $\mathrm{TCS}$ & Blowering dam, NSW \\
\hline & $\mathrm{B} 87: 8169$ & 7 & Redfin perch & TCS & Lake Nillahcootie, Victoria \\
\hline & $\mathrm{B} 86: 8774$ & 8 & Rainbow trout & TCS & Adaminaby, NSW \\
\hline & A94:0045 & 9 & Rainbow trout & TCS & Snowy Mts, NSW \\
\hline & A91:024 & 10 & Rainbow trout & TCS & Goulburn, Victoria \\
\hline BIV(1) & - & 11 & Frog & TCS & Queensland \\
\hline BIV(2) & - & 12 & Barramundi & TCS & Queensland \\
\hline FLDV & $89: 0248$ & 13 & Barramundi & Surface nodules & Northern Territory \\
\hline DPEV & 940074 & 14 & Diamond python & Erythrocytes & Melbourne, Victoria \\
\hline
\end{tabular}

and BIV $109 \pm 12 \mathrm{~kb}$ (Hengstberger et al. 1993). To date neither genome has been sequenced and thus sequences of the genome which are unique to either virus remain unknown.

DNA was extracted from purified EHNV and cloned into M13 bacteriophage vectors (Viera \& Messing 1982) and inserts sequenced using Sequenase (USB) according to the manufacturer's instructions. DNA sequences of several inserts were scanned for the presence of an open reading frame which served as the template for the synthesis of DNA deoxyoligonucleotides using an Applied Biosystems DNA synthesiser. Two primers P505 (5'-GATCCACACGGCCTGACACCG) and P506 (5'-GATCCGAAAGACAGCAGCGGTCGA) were designed to amplify sequences of approximately $300 \mathrm{bp}$ from trout EHNV using the polymerase chain reaction (PCR) (Saiki et al. 1988) using 30 cycles and parameters of $94^{\circ} \mathrm{C}$ for $1 \mathrm{~min}, 60^{\circ} \mathrm{C}$ for $2 \mathrm{~min}$ and $72^{\circ} \mathrm{C}$ for $2 \mathrm{~min}$ and reaction conditions as described for Taq DNA polymerase from Perkin Elmer-Cetus. DNA products were visualised using ethidium bromide staining of $2 \%$ agarose gels after electrophoresis in Tris-acetate-EDTA (TAE) buffer.

Hybridisation analyses and Southern blots were as described in Hengstberger et al. (1993) The PCR probe

Table 2. EHNV-infected fish used in this study. All samples represent pooled tissues (kidney, liver and spleen)

\begin{tabular}{|llc|}
\hline Virus & Host species & Sample no. \\
\hline EHNV (B86:8774) & Redfin perch & 15 \\
EHNV (B86:8774) & Rainbow trout & 16 \\
Uninfected & Redfin perch & 17 \\
Uninfected & Rainbow trout & 18 \\
\hline
\end{tabular}

was prepared by excising the EHNV DNA amplified after PCR and electrophoresis in a $2 \%$ agarose-TAE gel. This was purified using 'Geneclean' (Biolabs 101) and 5'-termini phosphorylated using T4 polynucleotide kinase and $\gamma^{32} \mathrm{P}$-ATP. Prior to hybridisation the labelled probe was denatured by heating to $100^{\circ} \mathrm{C}$ for 5 min and immediately placed on ice.

\section{RESULTS AND DISCUSSION}

The potential of the PCR test to detect the presence of EHNV is shown in Fig. 1A, B. The genomic DNA of several Australian iridoviruses were tested for their ability to generate a specific DNA fragment after PCR using synthetic DNA primers. It was observed that only EHNV (isolated from redfin perch and rainbow trout) and the closely related BIV (Hengstberger et al. 1993) genomes served as templates during the test. Neither fish lymphocystis virus (FLDV) nor a recently discovered iridovirus from a diamond python (DPEV) could be amplified (Fig. 1B) suggesting that the test is specific for EHNV and BIV. Alternatively, it could be argued that tissues containing FLDV and DPEV contain substances which may inhibit the PCR test. However, ELISA tests and immunoelectron microscopical analyses have shown that polyclonal antibodies against EHNV fail to recognise these antigens (data not shown) thus inferring that the viruses are significantly different from EHNV and BIV. In addition, positive controls consisting of FLDV or DPEV (as above) but containing EHNV DNA produced positive PCR products thus indicating that the original negative results were representative and not due to inhibition of the PCR reaction by exogenous material. Sequence of 


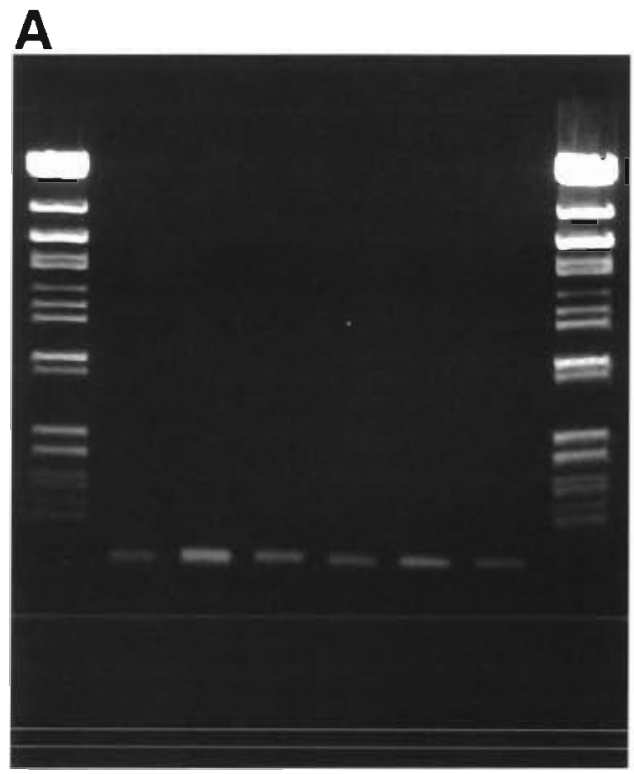

$\begin{array}{llllllll}a & b & c & d & e & f & g & h\end{array}$

\section{B}

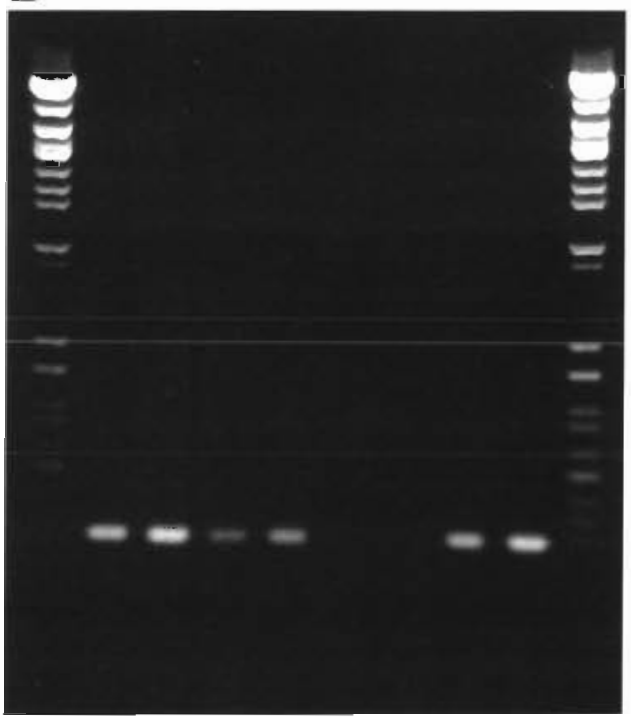

a $\quad b \quad c \quad d \quad$ e $\quad f \quad g \quad h \quad i \quad j$
C

$\mathrm{kb}$

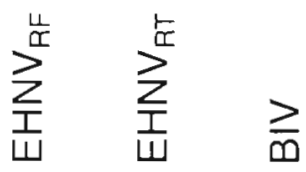

23.1-

$9.42-$

$6.68-$

$4.36-$

$2.32-$

$2.02-$

Fig. 1. DNA products from the polymerase chain reaction (PCR) amplification using primers P50S and P506 were revealed by electophoresis through a $2 \%$ agarose gel and staining with ethidium bromide. (A) Lanes: $(a, h) \lambda$ Ava II DNA markers; ( $b$ to g) samples 1 to 6 (see Table 1). (B) Lanes: $(a, j) \lambda$ Ava II DNA markers; (b) sample 7; (c) sample 8; (d) BIV (1); (e) BIV(2); (f) DPEV; (g) FLDV; (h) sample 9; (i) sample 10 (see Table 1). (C) Hybridisation of a ${ }^{32} \mathrm{P}$-labelled PCR fragment to Ncol restricted DNA from $\mathrm{EHNV}_{\mathrm{RF}}$. EHNV ${ }_{\mathrm{RT}}$ and BIV. Positions of $\lambda$ HindIII DNA size markers indicated in $\mathrm{kb}$

the PCR products showed that the sequences are essentially identical and therefore the primers are recognising the cognate region of each of the viral genomes; FLDV and DPEV do not possess the equivalent genomic regions (authors' unpubl. data).

Samples of EHNV isolated from fish originating from different regions of Victoria and NSW were also analysed for their ability to generate a positive signal using the PCR test. All were found to be positive. This indicated that within the limits of the PCR test there appeared to be no great genomic variability among the EHNV isolates such that some could not be amplified.
The sensitivity of the PCR test was analysed by performing PCR reactions on serial dilutions of a virus stock. Consistent positive signals were seen when at least 1 to 10 infectious virus particles were present in the initial sample material finally incorporated into the test sample (not shown).

Six samples from both uninfected rainbow trout and redfin perch were examined by $P C R$ with negative results. Virus isolation and antigen capture ELISA (Hyatt et al. 1991, Whittington \& Steiner 1993) also showed these samples to be negative and thus in light of their history (i.e. collected from geographical areas 


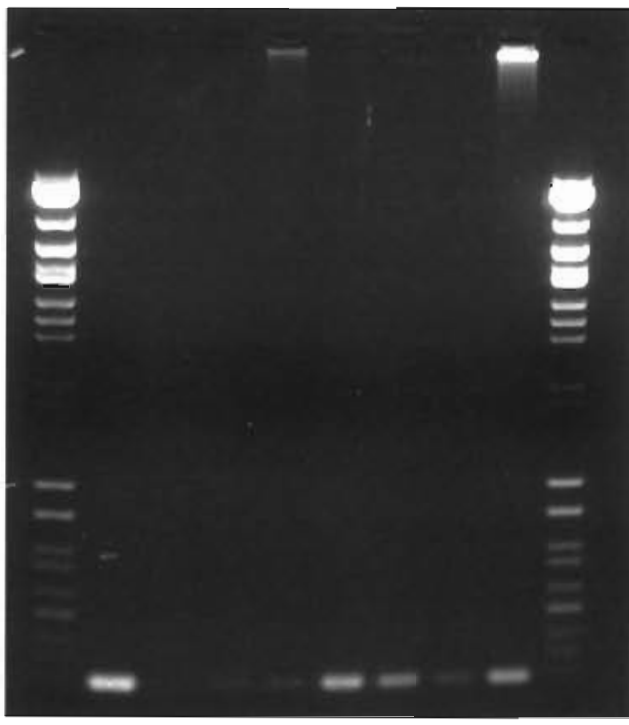

$\begin{array}{llllllllllllllllllll} & b & c & d & e & f & g & h & i & j\end{array}$

Fig. 2. DNA products from the polymerase chain reaction (PCR) amplification of primers P505 and P506 shown by ethidium bromide staining of a $2 \%$ agarose gel. Lanes: $(a, j) \lambda$ Ava II DNA markers; (b) positive EHNV control (tissue culture supernatant from EHNV-infected cells); (c) negative control (uninfected redfin perch); (d to f) sample 15 (DNA products from 3 dufferent experimentally infected redfin perch); (g to i) sample 16 (DNA products from 3 different experimentally infected rambow trout)

known to be EHNV-free) could be defined as EHNVnegative material. Analyses of DNA from experimentally infected redfin perch and rainbow trout showed the presence of EHNV positive PCR products (Fig 2).

Southern blot analysis of Ncol restricted EHNV and BIV genomic DNA using a labelled PCR probe derived from EHNV (Fig. 1C) showed that this probe could also be used in a simple diagnostic test to differentiate between these viruses despite their close homology (approximately $98 \%$ ) at the nucleotide level (authors' unpubl. data).

The results presented in this paper illustrate that the PCR test amplified target DNA from EHNV and the closely related BIV. The addition of this test to the panel of diagnostic protocols so far described for the detection of EHNV and BIV, namely antigen capture ELISA, fluorescence and electron microscopy (Hyatt et al. 1991, Steiner et al. 1991, Whittington \& Steiner 1993), will enhance the armouridium of diagnostic tests and facilitate future epidemiological, pathogenicity and carrier studies.

Acknowledgements. The authors express their appreciation to Dr L. Owens for the supply of BIV recovered from BIVinfected barramundi and Dr H. Macracken of the Melbourne Zoological Gardens for the supply of erythrocytes from a
DPEV-infected diamond python. Christie Kearns assisted in preparation of specimens for examination

\section{LITERATURE CITED}

Eaton BT, Hyatt AD, Hengstberger S (1991) Epizootic haematopoletic necrosis virus: purification and classification J Fish Dis 14:157-169

Essani K, Granoff A (1989) Amphibian and piscine iridoviruses proposal for nomenclature and taxonomy based on molecular and biological properties. Intervirology 30 : $181-193$

Francki RIB, Fauquet CM, Knudson DL, Brown F (eds) (1991) Classification and nomenclature of viruses. Arch Virol (Suppl 2):132-136

Hedrick RP, McDowell TS, Ahne W, Torhy C, de Kinkelin P (1992) Properties of three iridovirus-like agents associated with systemic infections of fish. Dis aquat Org 13:203-209

Hengstberger SG, Hyatt AD, Speare R, Coupar BEH (1993) Comparison of epizootic haematopoietic necrosis and Bohle iridoviruses, recently isolated Australian iridoviruses. Dis aquat Org 15:93-107

Hyatt AD, Eaton BT, Hengstberger S, Russel G (1991) Epizootic haematopoietic necrosis virus: detection by ELISA. immunohistochemistry and immunoelectron microscopy J Fish Dis 14:605-617

Langdon JS (1989) Experimental transmission and pathogenicity of epizootic haematopoietic necrosis virus (EHNV) in redfin perch, Perca fluviatilis L., and 11 other teleost5. J Fish Dis 12:295-310

Langdon JS, Humphrey JD, Williams LM (1988) Outbreaks of an EHNV-like iridovirus in cultured rainbow trout, Salmo gairdnerl Richardson, in Australia. J Fish D1s 11:93-96

Langdon JS, Humphrey JD, Williams LM, Hyatt AD, Westbury HA (1986) First virus isolation from Australian fish: an iridovirus-like pathogen from redfin perch, Perca fluviatilis L. J Fish Dis 9:263-268

Moody NJG, Owens L (1994) Experimental demonstration of the pathogenicity of a frog virus, Bohle iridovirus, for a fish species, barramundi Lates calcarifer. Dis aquat Org 18 95-102

Pearce M, Humphrey JD, Hyatt AD, Williams LM (1990) Lymphocystis disease in captive barramundi Lates calcarifer Aus Vet J 67:144-145

Saiki RK, Gelfand DH, Stoffel S, Scharf SJ, Higuchi R, Horn GT, Mullis KB, Erlich HA (1988) Primer-directed enzymatic amplification of DNA with a thermostable DNA polymerase. Science 239:487-491

Speare R, Smith JR (1992) An Iridovirus-like agent isolated from the ornate burrowing frog Limnodynastes ornatus in northern Australia. Dis aquat Org 14:51-57

Steiner KA, Whittington RJ, Petersen RK, Hornitzky C, Garnett $H$ (1991) Purification of epizootic haematopoietic necrosis virus and its detection using ELISA.J virol Meth 33:199-209

Vieira J, Messing $J$ (1982) The pUC plasmids, an M13 mp7derived system for insertion mutagenesis and sequencing with synthetic universal primers. Gene 19:259-268

Whittington RJ, Philbey GL, Reddacliff GL, Macgown AR (1994) Epidemiology of epizootic haematopoietic necrosis virus (EHNV) infection in farmed rainbow trout, Oncorhynchus mykiss (Walbaum): findings based on virus isolation, antigen capture ELISA and serology. J Fish Dis 17:205-218

Whittington RJ, Steiner KA (1993) Epizootic haematopoietic necrosis virus (EHNV): improved ELISA for detection in fish tissues and cell cultures and an efficient method for release of antigen from tissues $J$ virol Meth 43:205-220 